\title{
Identification of Disease and Efforts to Protect Natural Orchid Plants Against Fungi Infection in the Liwa Botanical Garden
}

\author{
Mahfut $^{1 *}$, Mitha Valentina Treesya Panjaitan ${ }^{1}$, Sri Wahyuningsih $^{1}$, Tundjung Tripeni Handayani ${ }^{1}$, Sukimin $^{2}$ \\ ${ }^{1}$ Department of Biology, Faculty of Mathematics and Natural Science, Universitas Lampung, Lampung, Indonesia. \\ ${ }^{2}$ Liwa Botanical Garden. Way Mengaku, Balik Bukit, Lampung Barat, Lampung, Indonesia \\ *Corresponding author E-mail: mahfut.mipa@unila.ac.id
}

\begin{abstract}
Liwa Botanical Garden is located in West Lampung Regency which has an area of 86.6 hectares and is one of the conservation of ornamental plants that presents the flora of the Bukit Barisan Selatan National Park. One of the flagship collections of this botanical garden is a native orchid. Disease infection is still a major obstacle in the cultivation and development of native orchid potential at Liwa Botanical Garden. Based on the results of previous studies, it is known that several individual natural orchid collections from Liwa Botanical Garden showed symptoms of fungal disease infections. Disease infections can inhibit plant growth and resistance and reduce the aesthetic value periodically. Symptoms of infection include necrotic patches on the upper surface of the leaf. This research was conducted to determine the identification of diseases and efforts to protect native orchids against fungal infections at Liwa Botanical Garden through a collection of samples that showed symptoms of infection, analysis of disease symptoms, and analysis of disease resistance levels. The results showed that the response of the native orchid at Liwa Botanical Garden to fungal infections was showed symptoms of wilting in the leaves, namely in the orchids Eria sp., Dendrobium sp., and Cymbidium sp. turns black on the edge of the leaf, Thrixspermum sp. The type of orchid most commonly infected with fungus is Cymbidium sp. a total of 8 samples, and Thrixspermum sp. 3 samples, Eria sp. as many as 4 samples, Dendrobium sp. and Calanthe triplicata as many as 6 samples. The type of native orchid that is most susceptible to fungal infections is Dendrobium sp. and Eria sp. with disease intensity of $74.11 \%$ and $22.3 \%$. The results of this activity are expected to be basic information in efforts to protect plants against diseases to support the application of conservation of native orchids on Liwa Botanical Garden.
\end{abstract}

Keywords: identification of diseases, fungal infections, orchid fungi, native orchids, liwa botanical garden

\section{Introduction}

Liwa Botanical Garden is located in Kubu Prahu Village, Balik Bukit District, Liwa-West Lampung Regency. This botanical garden has an area of 86.6 hectares which is one of the conservation of ornamental plants that presents the rich flora of the Bukit Barisan Selatan National Park [21], one of which is natural orchids. The native orchid collection at the Liwa Botanical Garden was obtained from exploration and donation activities. Until November 2013 there were 384 exploration numbers and 41 donation numbers from the Bogor Botanical Gardens [3]; [5]; [17].

Disease infection is still a major obstacle in the cultivation and development of natural orchid potential at Liwa Botanical Garden. Based on the results of previous studies, it is known that several individual natural orchid collections from Liwa Botanical Garden showed symptoms of fungal disease infections. Disease infections can inhibit plant growth and resistance and reduce the aesthetic value periodically. Symptoms of infection include necrotic patches on the upper surface of the leaf [2]; [8]; [9]. Plant diseases caused by fungi generally spread through the soil. The fungus can infect the root area and base of the stem, as a result the plant will experience wilting, seedling / sprout (damping-off), root rot, or root neck [4]; [10]; [11]; [12]; [14]; [15].

To facilitate the control of fungal diseases, an inventory of data is first carried out as basic information regarding the infection of the disease. Recognition of symptoms as an infection response is the first data in disease identification [16]. The data is used to determine disease intensity and plant resistance and control. Based on the above it is necessary to conduct research activities related to the identification of diseases and efforts to protect natural orchid plants against fungal infections at Liwa Botanical Garden. The results of this study are expected to be basic information in efforts to protect orchids to support the application of conservation at Liwa Botanical Garden. 


\section{MATERIALS AND METHODS}

\subsection{Sample Collection}

Sample collection was carried out on orchid leaves in Liwa Botanical Garden which showed symptoms of being infected with a virus. All samples were tabulated and documented with photos.

\subsection{Analysis of Disease Symptoms}

This analysis is done by matching the sample documentation with the literature that has been previously reported. The literature used is [17].

\subsection{Disease Intensity Analysis}

This stage is done to determine the severity of the disease (disease severity). Disease intensity is the proportion of infected hosts to the total observed surface area of the host. Calculation of disease intensity analysis is done using the method of [20] and the scale of disease intensity refers to [17].

\subsection{Plant Resistance Level}

Determination of the level of resistance of orchids to disease follows the method of [17].

\section{RESULTS AND DISCUSSION}

\subsection{Sample Collection}

The sample collection stage is conducted in the second week of January to the second week of February 2020. Samples are randomly selected from orchid individuals who show symptoms of fungal infection at the Liwa Botanical Garden green house. Based on the collection results obtained 21 samples from 5 types of orchids, i.e: Eria sp., Thrixspermum sp., Cymbidium sp., Dendrobium sp., Calanthe triplicata. The type of orchid that is most infected with fungi is Cymbidium sp. as many as 8 samples. Furthermore orchid Eria sp. 4 samples, Thrixspermum sp. as many as 3 samples, while Dendrobium sp. and Calanthe triplicata with 6 samples. Overall data collection results are shown in Table 1.

Table 1: Samples collection of native orchids at Liwa Botanical Garden which show symptoms of fungi infection

\begin{tabular}{llll}
\hline No. & Species of Orchid & Number of Sample & Symptoms of Infection \\
\hline 1 & Eria sp. & 4 & Wilting leaf on the middle to the tips of the leaves \\
2 & Cymbidium sp. & 8 & Wilting leaf on the middle to the tips of the leaves \\
3 & Thrixspermum sp. & 3 & The leaves turn black on the ping-gir of the leaf \\
4 & Dendrobium sp. & 6 & All the wilted leaves are yellow \\
5 & Calanthe triplicata & 6 & There are small black spots on the petals \\
\hline
\end{tabular}

The selection of sampling locations is based on previous research [17] which reported a fungal infection in the native orchid collection at Liwa Botanical Garden in August and December 2019. Types of orchids infected with fungi are Cymbidium and Corynborsis with mixed virus symptoms, fungus, and bacteria. In this study, Cymbidium sp. being the most orchid-infected type of orchid. This shows that this type of orchid is the most vulnerable host infected with pathogenic fungi. Apart from that are orchids Eria sp., Thrixspermum sp., Dendrobium sp., Calanthe triplicata. Other studies also report the presence of fungal infections with symptoms of wilting in 3 types of Dendrobium stratiotes, Dendrobium moschatum, Dendrobium concinnum, and Pteroceras unguiculatum at Bogor Botanical Gardens [1]. [7] also reported infection with Phalaenopsis sp. in Lembang, West Bandung with symptoms of fungus spots. Some research also shows that orchids in some locations are infected by fungus. Anita [1] reports that on Dendrobium sp. also showed a fairly severe fungal infection at Bogor Botanical Garden.

\subsection{Analysis of Disease Symptoms}

Based on the analysis of disease symptoms, orchid samples of Eria sp., Thrixspermum sp., Cymbidium sp., Dendrobium sp., And Calanthe triplicata. showing symptoms of fungal infections, namely leaves with black spots on the edges, leaves withering and dry, there are black spots on the flowers. Overall symptoms of fungal diseases infecting native orchids at Liwa Botanical Garden are showed on Fig. 1. 


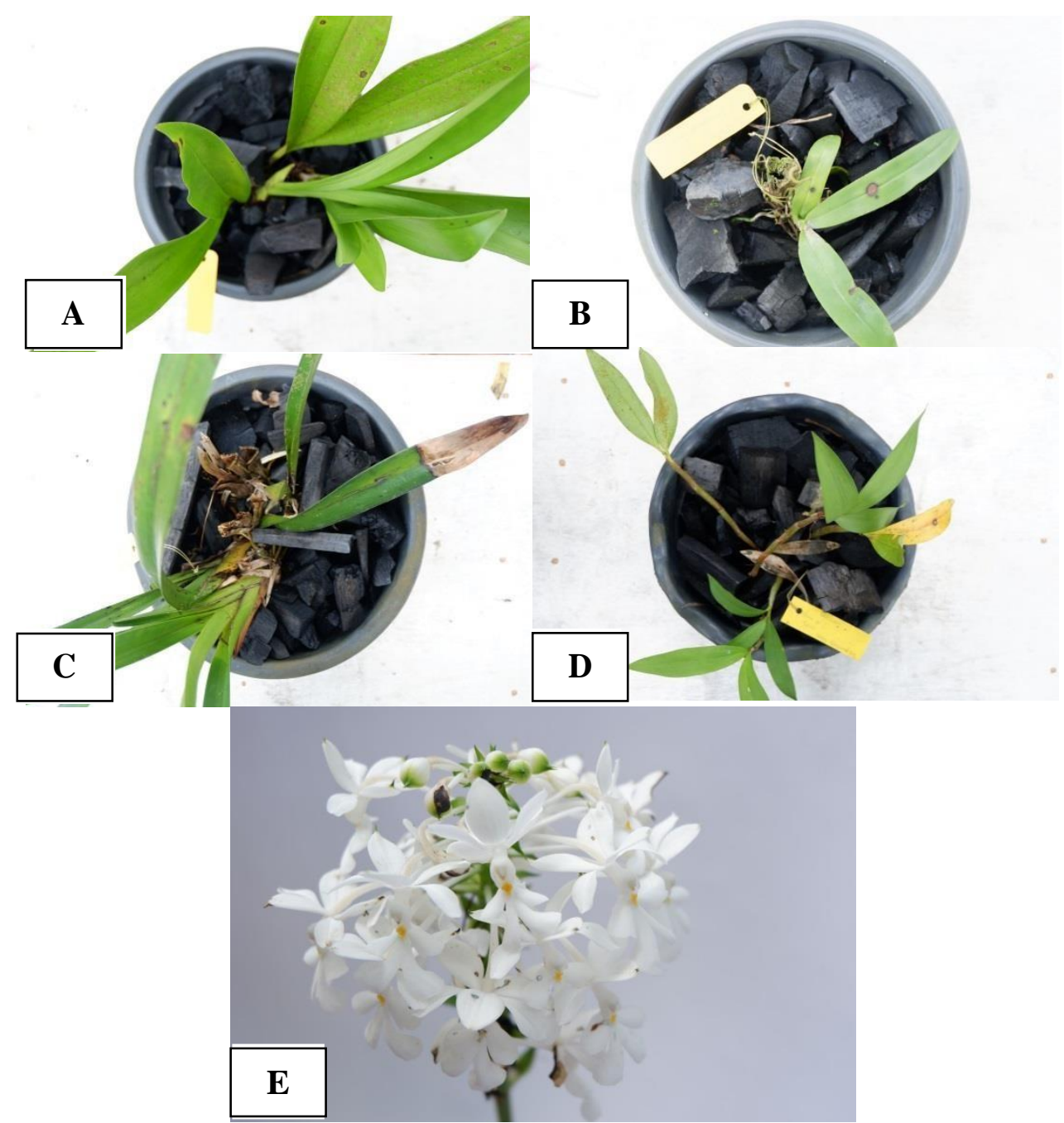

Fig. 1: Symptoms of fungal infections on native orchids at Liwa Botanical Garden: (A) Eria sp. (B) Thrixpermum sp. (C) Cymbidium sp. (D) Dendrobium sp. (E) Calanthe triplicata

Thrixspermum sp. symptoms caused by the leaves turn black on the edge of the leaf, looks like a spot. In Dendrobium sp. symptoms caused by all parts of the leaves withering yellow, the fungus that infects this orchid is Sclerotium rolfsii. On Eria sp. and Cymbidium sp. have the same symptoms, namely the leaves become dry brown there is the middle to the tip of the leaf. The fungus that infects this orchid is Phytoptora palmivora. In contrast to Calanthe triplicata the symptoms caused by this orchid are black spots on the flower. This infecting fungus is Botrytis cinerea. Whereas in Calanthe triplicata the infected part is a part of the flower. The symptoms that arise are black spots on the flower petals.

The difference in symptoms caused by several factors, one of which is the type of orchid. Each type of orchid shows a different character from one another [18]; [19]; [23]. The habitat of the orchid plant influences the growth of orchids such as the influence of sunlight, climate conditions, temperature, humidity and the availability of nutrients that support the growth of orchids, and affect the quality and quantity of flowers produced [6]; [13]; [22]; [24]. Overall symptoms of fungal diseases infecting natural orchids at Liwa Botanical Garden are showed on Fig. 2. 


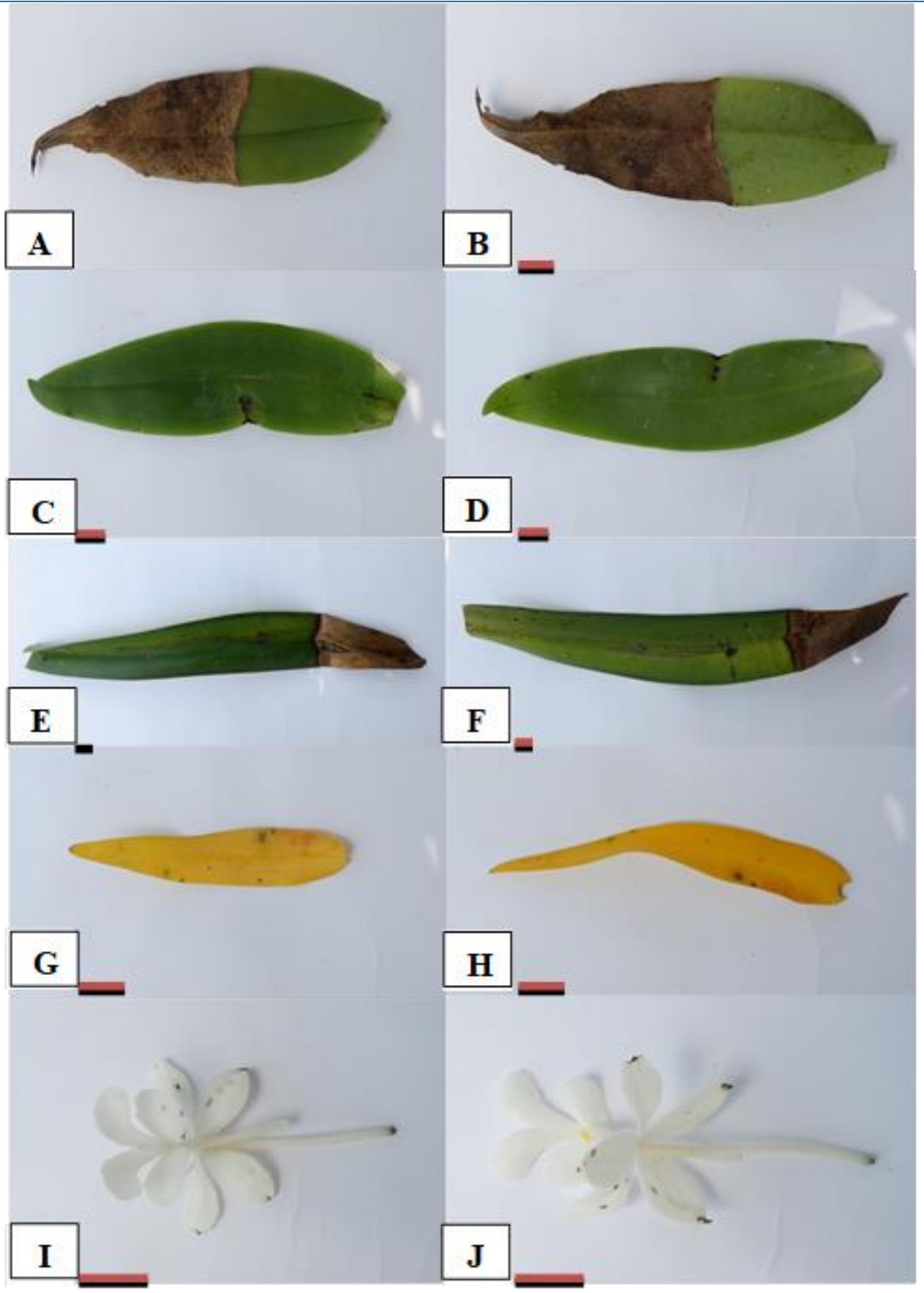

Fig. 2: Samples collection of symptoms of fungal infections on naive orchids at Liwa Botanical Garden:

(A, B) : Wilting leaf on Eria sp.

(C, D) : Wilting leaf on Thrixspermum sp.

(E, F) : Wilting leaf on Cymbidium sp.

$(\mathrm{G}, \mathrm{H}) \quad$ : Wilting leaf on Dendrobium $\mathrm{sp}$

(I, J) : Wilting leaf on Calanthe triplicata

(A, C, E, G, I): Top surface of the leaf and flower, (B, D, F, H, J): Surface under the leaf and flower. Bar: $1 \mathrm{~cm}$

\subsection{Disease Intensity}

The results of analysis of disease intensity of fungal diseases on native orchids at Liwa Botanical Garden, obtained the percentage of intensity as showed at Table 2.

Table 2: Analysis of fungal infection on native orchids at Liwa Botanical Garden

\begin{tabular}{lll}
\hline No. & Species of Orchid & Disease Intensity \\
\hline 1 & Eria sp. & $22,3 \%$ \\
2 & Cymbidium sp. & $3,63 \%$ \\
3 & Thrixspermum sp. & $3 \%$ \\
4 & Dendrobium sp. & $74,11 \%$ \\
5 & Calanthe triplicata & $12,63 \%$ \\
\hline
\end{tabular}


Dendrobium sp. has the highest disease intensity with a fairly high percentage of disease events at $74.11 \%$, with a total of 6 samples from a total of 17 leaves showing symptoms of fungal infections. In the orchid Eria sp. a total of 4 samples showed symptoms of fungal infections and the percentage of disease events was Eria sp. 22.3\%, but the intensity of the disease in this orchid is smaller when compared with Cybidium sp. The lower intensity of the disease on Eria sp. this is caused by the total number of leaves in one plant and the scale of infection categories in the leaves so that the comparison of Dendrobium sp. and Eria sp. is different. Unlike on Dendrobium sp. and Eria sp. which shows the percentage of disease intensity is quite high, because it has an intensity value above $20 \%$ compared to Calanthe triplicata, Cymbidium sp., Thrixspermum sp.

\subsection{Plant Resistance}

The results of the analysis of the level of resistance to fungal diseases in native orchids in Liwa Botanical Garden are showed on Table 3.

Table 3: Analysis of the level of plant resistance to fungal infections in the Liwa Botanical Garden

\begin{tabular}{llc}
\hline No. & Species of Orcid & Plant Resistance Level \\
\hline 1 & Eria sp. & Resistance \\
2 & Cymbidium sp. & Resistance \\
3 & Thrixspermum sp. & Resistance \\
4 & Dendrobium sp. & Susceptible \\
5 & Calanthe triplicata & Resistance \\
\hline
\end{tabular}

On Dendrobium sp. has a resistance level that is vulnerable because it has an incidence of more than $40 \%$, while other orchids have a rather resistant level.

\section{Conclusion}

Response of the native orchid at Liwa Botanical Garden to fungal infections was showed symptoms of wilting in the leaves, namely in the orchids Eria sp., Dendrobium sp., and Cymbidium sp. turns black on the edge of the leaf, Thrixspermum sp. The type of orchid most commonly infected with fungus is Cymbidium sp. a total of 8 samples, and Thrixspermum sp. 3 samples, Eria sp. as many as 4 samples, Dendrobium sp. and Calanthe triplicata as many as 6 samples. The type of native orchid that is most susceptible to fungal infections is Dendrobium sp. and Eria sp. with disease intensity of $74.11 \%$ and $22.3 \%$. The results of this activity are expected to be basic information in efforts to protect plants against diseases to support the application of conservation of native orchids on Liwa Botanical Garden.

\section{Acknowledgement}

Thank you to Liwa Botanical Garden who facilitated the research. This activity is a continuation of the collaboration program with Universitas Lampung.

\section{References}

[1] Anita DP (2017), Inventaris Penyakit Pada Tanaman Anggrek di Kebun Raya Bogor, Skripsi, Institut Pertanian Bogor.

[2] Anggraeni DN \& Sumiati E, 2019, Antagonistic Endosymbion Bacteria against Soft-Rot Bacteria in Phalaenopsis sp., The 1st International Conference on Science and Technology (ICoST), Makassar, Indonesia.

[3] Badu A (2013), Jenis-Jenis Pohon Inang Anggrek Alam di sekitar Jalur Pendakian Shelter I-II Gunung Nokilalaki di Kawasan Taman Nasional Lore Lindu, Skripsi, Universitas Tadulako.

[4] Benyon F, Summerell BA, Burgess LW (1996), Asosiasi spesies Fusarium dengan akar busuk anggrek Cymbidium, Australas. Pathol., vol. 25 (4), pp. 226-228.

[5] Cronquist A (1981), An Integrated ystmof Classification of Flowering Plants, Columbia University Press, New York.

[6] Darmono DW (2003), Menghasilkan Anggrek Silangan, Penebar Swadaya, Depok.

[7] Devi AK (2018), Identitas Spesies Botrytis pada Tanaman Hortikultura di Jawa Barat, Jurnal Fitopatologi Indonesia, vol. 14(6), pp. 205-214.

[8] Edwin N (2009), Teknik Pengendalian Hama Dan Penyakit Pada Anggrek Di Widoro Kandang Yogyakarta, Universitas Negeri Yogyakarta, Yogyakarta.

[9] Gandjar I, Samson RA, Van den Tweel-vermeulen K, Oetari A, \& Santoso I (1999), Pengenalan Kapang Tropik Umum, Yayasan Obor Indonesia, Jakarta.

[10] Gunawan LW (2005), Budidaya Anggrek, Penebar Swadaya, Depok, pp. 88.

[11] Hadi S, Saefuddin A, Achmad, \& Suryani A (2002), Epidemilogi hawar daun bibit Pinys merucii yang disebabkan oleh Pestalotia theae, J. Man. Hut. Trop., vol. 10(1), pp. 43-60.

[12] Herlinda S, Utama, MD, Pujiastuti Y, \& Suwandi (2006), Kerapatan dan Viabilitas Spora Beauveria bassiana (Bals.) Akibat Subkultur dan Pengayaan Media serta Virulensinya terhadap Larva Plutella xylostella (Linn.), J. HPT Tropika, vol. 6(2), pp. 102-112

[13] Hull R (2002), Matthews Plant Virology, An Diego: Academic Press.

[14] Ichikawa K, Aoki T (2000), Penyakit Bercak Daun Baru Dari Spesies Cymbidium disebabkan oleh Fusarium subglutinans dan Fusarium proliferatum. J. Gen. Plant Pathol., vol. 66 (3), pp. 213-218.

[15] Latiffah Z, Hayati MZN, Baharuddin S, \& Maziah Z (2009), Identifikasi dan Pathogenetikaspesies Fusarium yang Terkait dengan Busuk Akar dan Busuk Batang Dendrobium, Asian J. Plant Pathol.,vol. 3 (1), pp. 14-21.

[16] Mahfut (2019), Indonesia Darurat Konservasi: Sudah Amankah Kebun Raya Kita?, Prosiding Seminar Nasional Biodiversitas. UIN Alauddin Makasaar, pp. 1-6.

[17] Mahfut, Wahyuningsih S, \& Handayani TT (2019), Konservasi Anggrek Alam di Kebun Raya Liwa, Laporan Kemajuan Penelitian, Universitas Lampung.

[18] Matthews REF (1992), Plant Fundamental of Plant Virology, Academic Press inc., California. 
[19] Nuryani W, Silvia YE, Hanudin, Djatnika I, \& Marwoto B (2012), Kemangkusan Biobakterisida terhadap Penyakit Busuk Lunak (Pseudomonas viridiflava) pada Phalaenopsis, J. Hort., vol. 22(4), pp. 392-399.

[20] Rahardjo IB \& Suhardi (2008), Insidensi dan Intensitas Serangan Penyakit Karat Putih pada Beberapa Klon Krisan, Jurnal Holtikultura, vol. 18(3), pp. 312- 318

[21] Rosanti D \& Widianjaya RR (2018), Morfologi Orchidaceae di Kebun Raya Liwa Kabupaten Lampung Barat Provinsi Lampung, Sainmatika: Jurnal Ilmiah Matematika dan Ilmu Pengetahuan Alam, vol. 15(2), pp. 84-89.

[22] Soelistijono R (2015), Kajian Efektifitas Rhizoctonia sp. Mikoriza Dataran Rendah danSedang pada Tingkat Keparahan Penyakit (DSI) Anggrek Phalaenopsis amabilis terhadap Fusarium sp., Jurnal Biosaintifika, vol. 7 (2), pp. 112-119.

[23] Timper P, Minton NA, Johnson AW, Brenneman TB, Culbrreat AK, Burton GW, Baker SH, \& Gascho GJ (2001), Influence of Cropping System on Stem Rot (Sclerotium rolfsii), Meloydogyne arenaria, and The Nematode Antagonist Pasteuria penetrans in Peanut. Plant Disease, vol. 85, pp. 767-772.

[24] Umayah (2006), Identifikasi Isolat Phytophthora Asal Kakao, Jurnal Menara Perkebunan, vol. 742, pp. 76-85. 